\title{
Alcohol and malaria
}

\section{Opinion}

In a large scale clinical trial with malaria infected patients in RDCongo comparing ACTs with Artemisia infusion we observed a gender difference. Whilst both genders responded equally well to Artemisia, in the ACT-treated arm there was significantly more gametocyte carriage in females than males for days 14-28. Having no valid explanation for this observation, one may wonder if it due to differences in enzyme between males and females, like those which are responsible for a lower susceptibility of males to alcohol consumption. It is well known on the other hand that alcohol consumption, especially palm wine, is much higher for males than for females in tropical countries. ${ }^{1,2}$ During gametocytogenenesis malaria parasites hide in the bone marrow. Ethanol has an effect on bone marrow. Biopsies from 30 alcohol-dependent individuals were investigated. The findings took the form of heightened ineffective erythropoiesis in bone marrow associated with impaired iron utilization. Both may be detrimental to the survival of the gametocytes. ${ }^{3}$ The effect of ethanol on the in vitro growth of the malaria parasite Plasmodium falciparum was investigated during six days of incubation. A significant growth inhibition for ethanol concentrations was observed on each day. Malarial parasites are strongly inhibited by ethanol concentrations. ${ }^{4,5}$

Fever is accompanied by glycogen destruction. This was already discovered more than 100 years ago. Glycogen disappears from the liver during tetanus, diphtheria and pneumonia. A natural way of our body to fight parasites and diseases. It makes thus complete nonsense to fight fever in the early stages of a malaria infection. ${ }^{6,7}$ Alcohol also removes glycogen from the liver. ${ }^{8}$ Chronic ethanol consumption also results in a dramatic decrease in liver glycogen concentrations, which could be related to either a depressed rate of synthesis or an increased rate of breakdown. ${ }^{9}$ Macrophages, including Kupffer cells, appear to increase their production of cytokines in patients with alcoholic liver disease. Precursors of macrophages, i.e. monocytes with alcohol induced hepatitis produce greater amounts of TNF- $\alpha$ and reactive oxygen species. These data have been confirmed in animals. Malaria parasites are destroyed by oxidative species, like $\mathrm{NO}, \mathrm{H}_{2} \mathrm{O}_{2}$ or artemisinin peroxides. ${ }^{10-12}$ Wine is efficient against other pathogens. An in vitro study was undertaken to determine the potential for survival of enteric pathogens in common drinking beverages. Three carbonated soft drinks, two alcoholic beverages, skim milk, and water were inoculated with Salmonella, Shigella, and enterotoxigenic Escherichia coli and quantitative counts were performed over 2 days. The study showed poorest survival of all three organisms in wine, and greatest growth in milk and water.

Long-term intake of alcohol affects the immune system. Serum levels of immunoglobulins (total $\operatorname{IgE}$, $\operatorname{IgG}, \operatorname{IgM}$, and $\operatorname{IgA}$ ) therefore, were analyzed in adult chronic alcoholics in Indian population and were correlated with different epidemiological and alcohol-related parameters. The results showed that $98 \%$ of alcoholics had abnormal immunoglobulin levels and $92 \%$ showed high or very high total serum IgE levels compared to $24 \%$ of the control group. Several other studies have shown that that total serum IgE concentrations are increased in moderate alcohol consumers with respect to abstainers. This increase is independent of cofounders such as age, sex, liver disease, cigarette
Volume 6 Issue 4 - 2018

\section{Pierre Lutgen \\ IFBV-BELHERB, Luxembourg}

Correspondence: Pierre Lutgen, IFBV-BELHERB, BP 98 L-6905, Niederanven, Luxembourg, Email lutgenp@gms.lu

Received: July 18, 2018 | Published: August 08, 2018

smoking. ${ }^{13-16}$ In a recent paper we have shown how IgE contributes to malaria prophylaxis. ${ }^{17}$ Alcohol can increase the solubility of poorly soluble drugs and hence increase their bioavailability. And increases the intestinal permeability to indigested macromolecules..$^{18,19}$

\section{Palm wines}

A study from Niger showed that palm wine consumption may deplete the body's antioxidants against free radical attacks and render the body in a state of oxidative stress. ${ }^{20}$ In Nigeria a face-to-face ethnomedical survey on 1000 randomly selected families in confirmed the use of palm wines as antimicrobial agents and prophylactic agents against malaria. The hypothesized mechanism is that the ethanol content of the palm wines may increase membrane fluidity, altering ion channels and $\mathrm{K}^{+}$content of the infected erythrocytes thereby impairing motor performance of Plasmodia. ${ }^{21,22}$ Medicinal herbs can be infused in palm wine. Palm wine is added to the decoctions of bitter herbs to increase their palatability. Palm wine is very rich in potassium, sodium is only present in traces, a situation very similar to that of Artemisia annua. ${ }^{23}$ Many palm wines are rich in anthocyanins concentrated in the pericarp. Anthocyanins have a strong effect on hemozoin inhibition like in black or red grapes or in pomegranate. ${ }^{24,25}$

\section{Conclusion}

It is hard to outline a conclusion. Heavy alcohol drinking certainly never should be recommended. Alcoholism is a health problem. Lets rather listen to the French" Boire du vin rouge modérément est bon pour la santé".

\section{Acknowledgements}

None.

\section{Conflict of interest}

The author declares that there is no Conflict of interest.

\section{References}

1. Jerome M, Lucile CV, Michel I. Artemisia annua and Artemisia afra tea infusions were equal to or better than artesunate-amodiaquine (ACT) in treating Plasmodium falciparum malaria in a large scale, double blind, randomized clinical trial; 2018.

2. Chrostek L, Jelski W, Szmitkowski M, et al. Gender-related differences in hepatic activity of alcohol dehydrogenase isoenzymes and aldehyde dehydrogenase in humans. J Clin Lab Anal. 2003;17(3):93-96. 
3. Michot F, Gut J. Alcohol-induced bone marrow damage. A bone marrow study in alcohol-dependent individuals. Acta Haematol. 1987;78(4):252257.

4. Lell B, Binh VQ, Kremsner PG. Effect of alcohol on growth of Plasmodium falciparum. Wien Klin Wochenschr. 2000;112(10):451-452.

5. Milan NF, Kacsoh BZ, Schlenke TA. Alcohol consumption as selfmedication against blood-borne parasites in the fruit fly. Curr Biol. 2012;22(6):488-493.

6. Graham G, Poulton EP. The Influence of High Temperature on Protein Metabolism with reference to Fever. Int J Med. 1912;6(1):82-124.

7. Colla A. Archiv Ital de Biologie. 1896;26:120.

8. Salant W. The Influence of Alcohol on the Metabolism of Hepatic Glycogen. Proceedings of the Society for Experimental Biology and Medicine, Newyork: Columbia University; 1905. 17 p.

9. Van Horn CG, Ivester P, Cunningham CC. Chronic ethanol consumption and liver glycogen synthesis. Arch Biochem Biophys. 2001;392(1):145152.

10. Wheeler MD. Endotoxin and Kupffer cell activation in alcoholic liver disease. Alcohol Res Health. 2003;27(4):300-306.

11. Honchel R, Ray MB, Marsano L, et al. Tumor necrosis factor in alcoho enhanced endotoxin liver injury. Alcohol Clin Exp Res. 1992;16(4):665669

12. Sheth NK, Wisniewski TR, Franson TR. Survival of enteric pathogens in common beverages: an in vitro study. Am $J$ Gastroenterol. 1988;83(6):658-660.

13. Kumar Y, Lakshmi PVM, Minz RW, et al. Evaluation of Serum Immunoglobulins IgG, IgA, IgM and Total IgE in Chronic Alcoholics: A Community-based Study. Immunochem Immunopathol. 2015;1:102.

14. Lomholt FK, Nielsen SF, Nordestgaard BG. High alcohol consumption causes high IgE levels but not high risk of allergic disease. J Allergy Clin Immunol. 2016;138(5):1404-1413.
15. Vidal C, Armisén M, Domínguez-Santalla MJ, et al. Influence of alcoho consumption on serum IgE levels. Alcohol Clin Exp Res. 2002;26(1):5964.

16. Gonzalez-Quintela A, Vidal C, Gude F. Alcohol-induced alterations in serum immunoglobulin IgE levels in human subjects. Front Biosci. 2002; 7:e234-244.

17. Pierre Lutgen. Antibodies, Prophylaxis, Transmission. Pharm Pharmacol Int J. 2018;6(2):00155.

18. Jonas HF, Erik S, Christel AS Bergström. Concomitant intake of alcoho may increase the absorption of poorly soluble drugs. European Journal of Pharmaceutical Sciences. 2015;67:12-20.

19. Worthington BS, Meserole L, Syrotuck JA. Effect of daily ethanol ingestion on intestinal permeability to macromolecules. Am J Dig Dis. 1978;23(1):23-32.

20. Ogunro PS, Ologunagba PO. The effect of palm wine on lipid peroxidation and antioxidant status of rural dwellers in South West Nigeria. Niger Postgrad Med J. 2011;18(3):186-190.

21. Ibegbulem CO, Alisi CS. Medicinal values of Elaeis guineensis and Raphia hookeri wines. Journal of Research in Biology. 2012; 2(6):589-595.

22. Chi LM, Wu WG. Mechanism of hemolysis of red blood cell mediated by ethanol. Biochim Biophys Acta. 1991;1062(1):46-50.

23. Iwegbue CM, Ojelum AL, Bassey FI. A survey of metal profiles in some traditional alcoholic beverages in Nigeria. Food Sci Nutr. 2014; 2(6):724-733.

24. Singh R, Low ET, Ooi LC. The oil palm VIRESCENS gene controls fruit colour and encodes a R2R3-MYB. Nat Commun. 2014;5:4106.

25. Akkawi M, Abu-Lafi S, Abu-Remeleh Q, et al. HPLC separation of phenolic phytochemicals from grape peels and seeds water extracts and their in vitro antimalarial activities. Pharm Pharmacol Int J. 2018;6(4):253-259. 